\title{
Knowledge, Attitudes and Practices (KAP) related to the Pandemic (H1N1) 2009 among Chinese General Population: a Telephone Survey
}

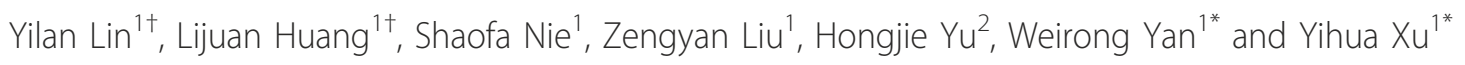

\begin{abstract}
Background: China is at greatest risk of the Pandemic (H1N1) 2009 due to its huge population and high residential density. The unclear comprehension and negative attitudes towards the emerging infectious disease among general population may lead to unnecessary worry and even panic. The objective of this study was to investigate the Chinese public response to H1N1 pandemic and provide baseline data to develop public education campaigns in response to future outbreaks.

Methods: A close-ended questionnaire developed by the Chinese Center for Disease Control and Prevention was applied to assess the knowledge, attitudes and practices (KAP) of pandemic (H1N1) 2009 among 10,669 responders recruited from seven urban and two rural areas of China sampled by using the probability proportional to size (PPS) method.
\end{abstract}

Results: $30.0 \%$ respondents were not clear whether food spread H1N1 virusand. 65.7\% reported that the pandemic had no impact on their life. The immunization rates of the seasonal flu and H1N1vaccine were $7.5 \%$ and $10.8 \%$, respectively. Farmers and those with lower education level were less likely to know the main transmission route (cough or talk face to face). Female and those with college and above education had higher perception of risk and more compliance with preventive behaviors. Relationships between knowledge and risk perception $(\mathrm{OR}=1.69$; $95 \% \mathrm{Cl} 1.54-1.86)$, and knowledge and practices $(\mathrm{OR}=1.57 ; 95 \% \mathrm{Cl} 1.42-1.73)$ were found among the study subjects. With regard to the behavior of taking up A/H1N1 vaccination, there are several related factors found in the current study population, including the perception of life disturbed $(\mathrm{OR}=1.29 ; 95 \% \mathrm{Cl} 1.11-1.50)$, the safety of $\mathrm{A} / \mathrm{H} 1 \mathrm{~N} 1$ vaccine $(\mathrm{OR}=0.07 ; 95 \% \mathrm{Cl} 0.04-0.11)$, the knowledge of free vaccination policy $(\mathrm{OR}=7.20 ; 95 \% \mathrm{Cl} 5.91-8.78)$, the state's priority vaccination strategy $(\mathrm{OR}=1.33 ; 95 \% \mathrm{Cl} 1.08-1.64)$, and taking up seasonal influenza vaccine behavior $(\mathrm{OR}=4.69 ; 95 \% \mathrm{Cl} 3.53-6.23)$.

Conclusions: This A/H1N1 epidemic has not caused public panic yet, but the knowledge of A/H1N1 in residents is not optimistic. Public education campaign may take the side effects of vaccine and the knowledge about the state's vaccination strategy into account.

\footnotetext{
*Correspondence: weirongy@gmail.com; xuyihua@mails.tjmu.edu.cn

† Contributed equally

'Department of Epidemiology and Biostatistics, School of Public Health, Tongji Medical College, Huazhong University of Science and Technology,

Wuhan 430030, China

Full list of author information is available at the end of the article
} 


\section{Background}

At the end of March 2009, an outbreak of novel influenza A (H1N1) (here after called A/H1N1) infection occurred in Mexico, followed by ongoing spread to all over the world in a short period [1]. On June 11 2009, the World Health Organization raised its pandemic alert level to the highest level, phase 6 [2], meaning that the A/H1N1 flu had spread in more than two continents and reached pandemic proportions. As of June 13, 2010, it had caused over 18,172 deaths in more than 214 countries and overseas territories or communities [3]. Most illness, especially the severe illness and deaths, had occurred among healthy young adults, which was markedly different from the disease pattern seen during epidemics of seasonal influenza $[4,5]$.

China is highly susceptible to $\mathrm{A} / \mathrm{H} 1 \mathrm{~N} 1$ because of its huge population and high residential density, besides the high infectiousness of this novel influenza virus. After the first imported case reported on May 11, 2009, the confirmed cases were reported in various provinces of China [6]. By the late of October 2009, A/H1N1 cases had increased dramatically, with 44,981 cases and 6 deaths confirmed at the end of October 2009. The A/ H1N1 infection rate peaked in November 2009, when approximately 1500 new cases of A/H1N1 were being confirmed each day. By the end of this month, a total of 92,904 cases and 200 deaths had resulted from A/ H1N1-related causes [7]. The Chinese government has taken a series of preventive measures according to WHO guidelines, including the promotion of public knowledge about flu through mass media, patient isolation, quarantine of close contact person, and free vaccinations to population at high risk (e.g. young children, healthcare workers, and people with chronic disease) [8]. However, there were few public reports on the assessment of the effect of these policies and the level of knowledge, attitude and practice (KAP) associating with A/H1N1 among general population.

It is well-known that confused comprehension and negative attitude towards the emerging communicable disease may lead to unnecessary worry and chaos, even excessive panic which would aggravate the disease epidemic [9]. For instance, during SARS epidemic from 2002 to 2004, the misconceptions and the excessive panic of Chinese public to SARS led the public resistant to comply with the suggested preventive measures such as avoiding public transportation, going to hospital when they were sick, which contributed to the rapid spread of SARS and resulted in a more serious epidemic situation, making China one of the worst affected countries with over 5327 cases and 439 deaths $[10,11]$. In addition, the panic of infectious disease outbreak could cause huge economic loss, for example the economic loss of SARS has been estimated at $\$ 30-\$ 100$ billion in US, though less than 10,000 persons were infected [12]. SARS experience has demonstrated the importance of monitoring the public perception in disease epidemic control, which may affect the compliance of community to the precautionary strategies. Understanding related factors affecting people to undertake precautionary behavior may also help decision-makers take appropriate measures to promote individual or community health. Therefore, it is important to monitor and analyze the public response to the emerging disease.

To investigate community responses to $\mathrm{A} / \mathrm{H} 1 \mathrm{~N} 1$ in China, we conducted this telephone survey to describe the knowledge, attitudes and practices of $\mathrm{A} / \mathrm{H} 1 \mathrm{~N} 1$ among general population in China and put forward policy recommendations to government in case of future similar conditions.

\section{Methods}

\section{Study sites}

This study was performed in seven urban regions (Beijing, Shanghai, Wuhan, Jingzhou, Xi'an, Zhengzhou, Shenzhen cities) and two rural areas (Jingzhou and Zhengzhou counties) of China with over one million people in each region. Regarding the urban sites, Beijing as the capital of China locates in the northeast; Shanghai is a municipality in the east of China; Wuhan (the provincial capital of Hubei) and Zhengzhou (the provincial capital of Henan province) are both in the centre of China; Xi'an in the northwest of China is the provincial capital of Shanxi province; and Shenzhen of the Guangdong province is in the southeast of China. As for the rural sites, Jingzhou county and Zhengzhou county, from Hubei and Henan provinces, respectively, both locate in the centre of China.

\section{Sample size}

This current study was carried out in three phases during the pandemic peak season of A/H1N1. The first phase was from 30 November 2009 to 27 December 2009, the second from 4 January 2010 to 24 January 2010, and the third from 24 February to 25 March in 2010.

A two-stage proportional probability to size (PPS) sampling method was used in each phase. In stage I, about $30 \%$ of administrative regions in each study site were selected as primary sample units (PSUs) for cluster sampling. In stage II, telephone numbers were sampled randomly, of which the first four digitals were obtained from each PSU's post office as initial number and the other three or four digitals were obtained from random number generated by Excel 2003. Then each family was chosen as per unit (excluding school, hotel public or cell phone etc.) and at least 400 families in each site at each phase were selected finally. If the family was 
selected repeatedly or refused to answer the questionnaire, we added one to the last digit of phone number and dial again. If the line was busy or of no response, we would dial three times and then give up this phone number if there was still no respondent.

\section{Telephone Survey}

Anonymous telephone interviews were conducted from 6:30 pm to $10: 00 \mathrm{pm}$ so as to avoid over-presenting the non-work population by well-trained interviewers with Bachelor degree of Epidemiology. The Questionnaire to Survey the Level of Knowledge, Attitude and Practice in Different Stages of A/H1N1 Pandemic by Telephone was designed by the Chinese Centre for Disease Control and Prevention (China CDC, Beijing). The majority of the questions were closed-ended and variables in the questionnaire were categorical, except age. The inclusion criteria of subjects were: age $\geq 18$ and proper communication skills. There were seven questions related to the knowledge of $\mathrm{A} / \mathrm{H} 1 \mathrm{~N} 1$, four referred to the attitude, and five concerning about the practice in this questionnaire (See additional file 1: The Questionnaire to Survey the Level of Knowledge, Attitude and Practice in Different Stages of H1N1 Pandemic by Telephone in China).

This study was approved by the institutional review board of the Tongji Medical College of Huazhong University of Science and Technology. All respondents were informed consent. We respected their wishes whether to accept our survey and promised to protect their secrets.

\section{Data analysis}

All data were entered into computer using Epidata V.3.1 and were analyzed in SPSS statistical software V.12. Chi-square test was applied to compare the immunization rates of the seasonal flu and $\mathrm{A} / \mathrm{H} 1 \mathrm{~N} 1$ vaccine. The associations between the socio-demographic factors and the KAP regarding $\mathrm{A} / \mathrm{H} 1 \mathrm{~N} 1$ were firstly investigated by using univariate odds ratios (OR) and then stepwise logistic regression modeling applied. Adjusting for such background variables including gender, age, level of education, occupation, region, and survey wave, stepwise multivariate logistic regression models were applied to investigate the impact factors associated with the risk perception of $\mathrm{A} / \mathrm{H} 1 \mathrm{~N} 1, \mathrm{~A} / \mathrm{H} 1 \mathrm{~N} 1$ vaccination uptake and the compliance with suggested preventive measures (avoid crowd places/wash hand frequently/keep distance from people with influenza-like symptoms). For the purposes of analysis, the factor knowledge about the main modes of transmission was divided into two groups according to whether the respondents knew both cough and talk faceto-face can spread A/H1N1. Odds ratios and respective 95\% confidence intervals $(\mathrm{CI})$ were obtained from the logistic regression analysis. $P$ values lower than 0.05 were judged to be statistically significant.

\section{Results}

\section{Socio-demographic characteristics}

A total of 88541 telephone numbers were dialed. Except 65323 invalid calls (including vacant numbers, fax numbers, busy tone numbers and non-qualified respondents whose age $<18$ and whose phones were from school, hotel or other public places), 23218 eligible respondents were identified. Among these respondents, 12360 completed the interview. Therefore, the response rate was 46.8\%. Excluding missing, and logical erroneous data, 10669 questionnaires in total were eligible for analysis. The baseline characteristics of the respondents were presented in Table1. The mean age of all respondents was 41.47 years (over range: 18-90 year). Of all respondents, $54.4 \%$ were female, and $42.4 \%$ had received college or above education (Table 1 ).

\section{Knowledge related to the Pandemic (A/H1N1) 2009}

The overall KAP related to $\mathrm{A} / \mathrm{H} 1 \mathrm{~N} 1$ was reported in Table 2. As to knowledge, $75.6 \%$ of all respondents knew that influenza could be transmitted by coughing and sneezing, and $61.9 \%$ thought that talking face-to-face was the transmission route, whereas $30.0 \%$ believed the transmission could be through food. Less than one third of respondents knew that virus could be transmitted by handshaking and indirect hand contact $(26.8 \%$ and $22.3 \%$, respectively). Multiple logistic regression analysis showed that those with middle school $(\mathrm{OR}=1.71$; $95 \% \mathrm{CI} 1.48$ $1.98)$, or having an education level of college and above $(\mathrm{OR}=2.16$; 95\%CI 1.83-2.54) were more likely to know the transmission routes comparing with other people. Comparing with students, teachers $(\mathrm{OR}=1.46$; $95 \% \mathrm{CI}$ 1.09-1.96) were more likely to answer the above questions

Table 1 Characteristics of the 10669 respondents, China

\begin{tabular}{llll}
\hline Characteristics & & No. & $\%$ \\
\hline Gender & Male & 4864 & 45.6 \\
Age group (y) & Female & 5805 & 54.4 \\
& $18 \sim$ & 1446 & 13.5 \\
& $25 \sim$ & 5898 & 55.3 \\
Occupation & $50 \sim$ & 2173 & 20.4 \\
& $65 \sim$ & 1152 & 10.8 \\
& Student & 729 & 6.8 \\
& Teacher & 429 & 4.0 \\
& Health care worker & 338 & 3.2 \\
& Office staff & 2681 & 25.1 \\
& Worker & 1069 & 10.0 \\
& Farmer & 1212 & 11.4 \\
& Public service personnel & 848 & 8.0 \\
& Others & 3363 & 31.5 \\
Educational background & Primary school and illiterate & 1202 & 11.3 \\
& Middle school & 4943 & 46.3 \\
& College and above & 4524 & 42.4 \\
\hline
\end{tabular}


Table 2 KAP of pandemic (H1N1)2009 among 10669 respondents, China n (\%)

\begin{tabular}{|c|c|c|c|}
\hline Questions & Yes (1) & No (2) & not clear (3) \\
\hline \multicolumn{4}{|l|}{ Knowledge: } \\
\hline \multicolumn{4}{|l|}{ Transmission route(1-5) } \\
\hline 1. Cough and sneeze & $8063(75.6)$ & 1020(9.5) & 1586(14.9) \\
\hline 2. Face-to-face talk & $6599(61.9)$ & 2084(19.5) & 1986(18.6) \\
\hline 3. Hand shaking or embracement & 2854(26.8) & $5185(48.6)$ & $2630(24.6)$ \\
\hline 4. Indirect hand contact & 2383(22.3) & $5390(50.5)$ & $2896(27.2)$ \\
\hline 5. Food & $3204(30.0)$ & $4470(41.9)$ & 2995(28.1) \\
\hline 6. Know the free vaccination policy & $7601(71.2)$ & $3068(28.8)$ & - \\
\hline 7. Know the state's initial vaccination strategy & $7280(68.2)$ & 3389(31.8) & - \\
\hline \multicolumn{4}{|l|}{ Attitudes: } \\
\hline 1. Has your daily life been disturbed by A/H1N1 & $3581(33.6)$ & $7011(65.7)$ & $77(0.7)$ \\
\hline 2. Do you worry about suffering from H1N1? & $2679(25.1)^{*}$ & $7720(72.4)^{*}$ & $270(2.5)^{*}$ \\
\hline 3.Approve of the state's initial vaccination strategy? & 10248(96.1) & $421(3.9)$ & - \\
\hline 4. Be afraid of H1N1 vaccine 's adverse reaction & $982(9.2)^{\dagger}$ & $7460(69.9)^{\dagger}$ & $2227(20.9)^{\dagger}$ \\
\hline \multicolumn{4}{|l|}{ Practices: } \\
\hline 1. Have taken up seasonal influenza vaccine & $797(7.5)$ & $9872(92.5)$ & - \\
\hline 2. Have taken up influenza $A(\mathrm{H} 1 \mathrm{~N} 1)$ vaccine & $1150(10.8)$ & $9519(89.2)$ & - \\
\hline 3. Avoid crowd places & $4574(42.9)$ & $5967(55.9)$ & $128(1.2)$ \\
\hline 4. Wash hand frequently & $6049(56.9)$ & $4311(40.56)$ & $267(2.5)$ \\
\hline 5. Keep distance from people with influenza-like symptoms & $6119(57.4)$ & $4011(37.6)$ & $539(5.0)$ \\
\hline
\end{tabular}

*: For this question, 1 refers to no, 2 refers to a little, 3 refers to very much.

': For this question, 1 refers to afraid, 2 refers to not afraid, 3 refers to don't care.

-: no this answer set.

correctly, but workers $(\mathrm{OR}=0.77 ; 95 \% \mathrm{CI} 0.62-0.97)$ and farmers $(\mathrm{OR}=0.63$; $95 \% \mathrm{CI} 0.49-0.80$ ) were less likely (present in Table 3). As time went by, the related knowledge of $\mathrm{H} 1 \mathrm{~N} 1$ among residents increased $(\mathrm{OR}=1.20 ; 95 \% \mathrm{CI}$ 1.08-1.34).More than half of the respondents knew prevention and control strategies for pandemic influenza in China, of which, $72.2 \%$ knew that $\mathrm{A} / \mathrm{H} 1 \mathrm{~N} 1$ vaccination was free of charge and $68.2 \%$ were informed about the state's initial vaccination strategy.

\section{Attitudes towards the Pandemic (A/H1N1) 2009}

Of all respondents, $33.6 \%$ considered that the influenza pandemic disturbing their daily lives, but did not result in public panic as $72.4 \%$ indicated they did not worry about suffering from A/H1N1. Multiple logistic regression analysis showed that females $(\mathrm{OR}=1.24 ; 95 \% \mathrm{CI}$ 1.14-1.36), people having college and above education $(\mathrm{OR}=1.23$; 95\%CI 1.02-1.49), people knowing the main modes of transmission $(\mathrm{OR}=1.69 ; 95 \% \mathrm{CI} 1.54-1.86)$ and the state's initial vaccination strategy $(\mathrm{OR}=1.12$; $95 \% \mathrm{CI}$ 1.01-1.24) were more likely to believe that they were at high risk of being infected. As time went by, the risk perception decreased (OR $=0.54$; 95\%CI 0.48-0.60) (in Table 3 and Table 4). Regarding the A/H1N1vaccination, $69.9 \%$ respondents believed that the occurrence rate of adverse reactions caused by $\mathrm{A} / \mathrm{H} 1 \mathrm{~N} 1$ vaccination was fairly low and they were not afraid of taking up vaccination. Most residents (96.1\%) thought that the state's vaccination strategy was reasonable.

\section{Practices related to the Pandemic (A/H1N1) 2009}

About half of the respondents (42.9\%) had avoided going to crowded places during the past two weeks of our survey. In case people nearby held influenza-like symptoms such as fever or cough, $56.9 \%$ increased the frequency of hand-washing and $57.4 \%$ would stay away from them. Multiple logistic regression analysis indicated compliance with the preventive practices were more likely to be taken by those who were females $(\mathrm{OR}=1.41 ; 95 \% \mathrm{CI}$ $1.28-1.55)$, old people above 65 years old $(\mathrm{OR}=1.34$; 95\% CI 1.06-1.69), people with education level middle school $(\mathrm{OR}=2.00 ; 95 \% \mathrm{CI} 1.71-2.34)$ or College and above $(\mathrm{OR}=1.98 ; 95 \% \mathrm{CI} 1.64-2.38)$, people perceiving a higher risk of being infected $(\mathrm{OR}=2.09$; $95 \% \mathrm{CI} 1.84$ 2.37) and those who knew the main modes of transmission $(\mathrm{OR}=1.57$; $95 \% \mathrm{CI} 1.42-1.73)$, but less likely to be taken by staff working in office $(\mathrm{OR}=0.76$; $95 \% \mathrm{CI} 0.59$ $0.97)$ and farmers $(\mathrm{OR}=0.70$; $95 \% \mathrm{CI} 0.53-0.94)$ comparing with students. As time went by, public became less likely to take the preventive practices $(\mathrm{OR}=0.70 ; 95 \% \mathrm{CI}$ 0.53-0.94). (in Table 3 and Table 4).

The immunization rates of the seasonal flu and A/ H1N1 in respondents were $7.5 \%$ and $10.8 \%$ respectively. The multivariate stepwise models further showed that 
Table 3 Associations between background characters and KAP regarding A/H1N1

\begin{tabular}{|c|c|c|c|c|c|c|c|c|}
\hline \multirow[b]{2}{*}{ Variables } & \multicolumn{2}{|c|}{$\begin{array}{l}\text { Know the main modes of } \\
\text { transmission }\end{array}$} & \multicolumn{2}{|c|}{$\begin{array}{l}\text { worry about infection of } \\
\text { A/H1N1 }\end{array}$} & \multicolumn{2}{|c|}{$\begin{array}{l}\text { take up preventive } \\
\text { measures }\end{array}$} & \multicolumn{2}{|c|}{$\begin{array}{l}\text { take up } A / H 1 N 1 \\
\text { vaccination }\end{array}$} \\
\hline & Row\% & $\mathrm{OR}_{\mathrm{m}}(95 \% \mathrm{Cl})$ & Row\% & $\mathrm{OR}_{\mathrm{m}}(95 \% \mathrm{Cl})$ & Row\% & $\mathrm{OR}_{\mathrm{m}}(95 \% \mathrm{Cl})$ & Row\% & $\mathrm{OR}_{\mathrm{m}}(95 \% \mathrm{Cl})$ \\
\hline \multicolumn{9}{|l|}{ Gender } \\
\hline Male & 58.5 & NU & 25.5 & 1.00 & 75.4 & 1.00 & 11.1 & NU \\
\hline Female & 58.4 & & 29.5 & $1.24(1.14-1.36)^{\ddagger}$ & 80.4 & $1.41(1.28-1.55)^{\ddagger}$ & 10.5 & \\
\hline \multicolumn{9}{|l|}{ Age (years) } \\
\hline $18 \sim$ & 60.5 & 1.00 & 31.1 & 1.00 & 79.1 & 1.00 & 20.5 & 1.00 \\
\hline $25 \sim$ & 60.9 & $1.07(0.93-1.24)^{*}$ & 30.1 & $1.10(0.94-1.29)^{\ddagger}$ & 79.1 & $1.18(0.99-1.40)$ & 10.7 & $1.15(0.91-1.46)^{\dagger}$ \\
\hline $50 \sim$ & 54.4 & $1.04(0.88-1.24)$ & 23.0 & $0.87(0.72-1.04)$ & 75.3 & $1.12(0.92-1.38)$ & 6.4 & $0.78(0.57-1.05)^{*}$ \\
\hline $65 \sim$ & 50.5 & $0.87(0.72-1.06)^{*}$ & 19.5 & $0.77(0.62-0.96)^{\dagger}$ & 77.2 & $1.34(1.06-1.69)^{*}$ & 7.0 & $0.92(0.65-1.30)$ \\
\hline \multicolumn{9}{|l|}{ Education } \\
\hline Primary school and illiterate & 38.0 & 1.00 & 22.7 & 1.00 & 64.6 & 1.00 & 4.7 & 1.00 \\
\hline Middle school & 55.6 & $1.71(1.48-1.98)^{\dagger}$ & 26.3 & $1.12(0.95-1.33)$ & 79.3 & $2.00(1.71-2.34)^{\ddagger}$ & 8.9 & $1.12(0.82-1.53)$ \\
\hline College and above & 66.9 & $2.16(1.83-2.54)^{\ddagger}$ & 30.4 & $1.23(1.02-1.49) *$ & 80.4 & $1.98(1.64-2.38)^{\ddagger}$ & 14.5 & $1.09(0.78-1.52)$ \\
\hline \multicolumn{9}{|l|}{ Occupation } \\
\hline Student & 62.7 & 1.00 & 33.1 & 1.00 & 80.3 & 1.00 & 35.9 & 1.00 \\
\hline Teacher & 73.2 & $1.46(1.09-1.96)^{\ddagger}$ & 36.8 & $1.12(0.84-1.50)^{\dagger}$ & 82.5 & $0.94(0.66-1.33)$ & 28.0 & $0.67(0.48-0.94)^{\neq}$ \\
\hline Health care worker & 71.0 & $1.31(0.97-1.78)^{\dagger}$ & 29.6 & $0.74(0.54-1.02)$ & 87.3 & $1.36(0.91-2.03)^{\dagger}$ & 46.2 & $1.52(1.09-2.11)^{\ddagger}$ \\
\hline Office staff & 67.1 & $1.08(0.88-1.33)^{+}$ & 29.4 & $0.81(0.65-1.01)$ & 78.0 & $0.76(0.59-0.97)^{\dagger}$ & 7.9 & $0.13(0.10-0.17)^{\ddagger}$ \\
\hline Worker & 54.4 & $0.77(0.62-0.97)^{\dagger}$ & 26.6 & $0.74(0.58-0.95)$ & 81.0 & $0.99(0.74-1.31)$ & 6.6 & $0.12(0.09-0.17)^{\ddagger}$ \\
\hline Farmer & 41.3 & $0.63(0.49-0.80)^{\ddagger}$ & 25.5 & $0.76(0.59-0.99)$ & 69.1 & $0.70(0.53-0.94)^{\dagger}$ & 3.1 & $0.06(0.04-0.10)^{\neq}$ \\
\hline Public service personnel & 57.6 & $0.81(0.64-1.02) *$ & 28.4 & $0.80(0.63-1.03)$ & 80.3 & $0.89(0.67-1.18)$ & 10.9 & $0.19(0.14-0.26)^{\dagger}$ \\
\hline Others & 55.0 & $0.83(0.67-1.02)^{\dagger}$ & 24.6 & $0.66(0.53-0.83)^{\ddagger}$ & 78.1 & $0.74(0.57-0.96)^{\dagger}$ & 5.9 & $0.11(0.08-0.15)^{\ddagger}$ \\
\hline \multicolumn{9}{|l|}{ Survey wave } \\
\hline 30 Nov 2009-27 Dec 2009 & 56.9 & 1.00 & 34.3 & 1.00 & 82.6 & 1.00 & 9.1 & 1.00 \\
\hline 4 Jan 2010-24 Jan 2010 & 57.7 & $1.08(0.98-1.20)$ & 26.6 & $0.70(0.62-0.78)$ & 77.7 & $0.91(0.80-1.03)$ & 9.7 & $1.12(0.92-1.33)$ \\
\hline 24 Feb 2010-25 Mar 2010 & 60.6 & $1.20(1.08-1.34)^{\dagger}$ & 22.1 & $0.54(0.48-0.60)^{\ddagger}$ & 74.1 & $0.71(0.62-0.80)^{\ddagger}$ & 13.5 & $1.67(1.40-1.99)$ \\
\hline
\end{tabular}

$\mathrm{OR}_{\mathrm{m}}$ : odds ratio obtained from stepwise multivariate logistics regression analysis using univariately significant variables as candidate variables and adjusting for region;

NU: not significant in the univariate analysis;

*: $P<0.05$;

†: $P<0.01$

$\neq: P<0.0001$.

except the health care workers $(\mathrm{OR}=1.52 ; 95 \% \mathrm{CI}$ 1.09-2.11), residents in other occupations $(\mathrm{OR}=0.06$ $0.67)$ were less likely to take up the $\mathrm{A} / \mathrm{H} 1 \mathrm{~N} 1$ vaccination comparing with students (in Table 3). Adjusting for the background covariates the knowledge about the free vaccination policy $(\mathrm{OR}=7.20 ; 95 \% \mathrm{CI} 5.91-8.78)$ and the state's initial vaccination strategy $(\mathrm{OR}=1.33$; $95 \% \mathrm{CI} 1.08$ 1.64), perception of daily life disturbed (OR $=1.29$; $95 \%$ CI 1.11-1.50), practice of injecting the seasonal influenza vaccine $(\mathrm{OR}=4.69 ; 95 \% \mathrm{CI} 3.53-6.23)$ were significantly associated with behavior of taking up the $\mathrm{A} / \mathrm{H} 1 \mathrm{~N} 1$ vaccination positively (in Table 5), and the adverse reaction of $\mathrm{A} / \mathrm{H} 1 \mathrm{~N} 1$ vaccine negatively influenced people's practice $(\mathrm{OR}=0.07 ; 95 \% \mathrm{CI} 0.04-0.11)$.

\section{Discussion}

Novel A/H1N1 has caused pandemic in this century. It is important to encourage the public to adopt precautionary behaviors, which is based on the correct knowledge of the epidemic and appropriate response among residents. Many studies have examined the various levels of KAP about infectious disease outbreaks, such as SARS, avian influenza [13-15]. Some studies have been reported specifically on community responses to $\mathrm{A} / \mathrm{H} 1 \mathrm{~N} 1$ in Australia and Europe $[16,17]$. But through literature search, we haven't found any public reports on KAP regarding A/H1N1 among Chinese population until now. Therefore, we conducted this large population-based survey (10669 respondents) to investigate community responses to $\mathrm{A} / \mathrm{H} 1 \mathrm{~N} 1$ and to provide baseline data to government for preventive measures in case of future outbreaks.

Unless people have basic knowledge about the modes of transmission, they respond appropriately during an outbreak [16]. It has been proved that influenza is transmitted through person to person via respiratory secretions [18]. Most residents in our survey recognized that 
Table 4 Factors associated with the risk perception of A/H1N1 or taking up preventive measures in daily life

\begin{tabular}{|c|c|c|c|c|c|c|}
\hline \multirow[b]{2}{*}{ Variables } & \multicolumn{3}{|c|}{ Worry about infection of $\mathrm{A} / \mathrm{H} 1 \mathrm{~N} 1$} & \multicolumn{3}{|c|}{ Take up preventive measures in daily life } \\
\hline & Row\% & $\mathrm{OR}_{\mathrm{u}}(95 \% \mathrm{Cl})$ & $\mathrm{OR}_{\mathrm{m}}(95 \% \mathrm{Cl})$ & Row\% & $\mathrm{OR}_{\mathrm{u}}(95 \% \mathrm{Cl})$ & $\mathrm{OR}_{\mathrm{m}}(95 \% \mathrm{Cl})$ \\
\hline \multicolumn{7}{|c|}{ Know the main modes of transmission } \\
\hline No & 21.8 & 1.00 & 1.00 & 71.9 & 1.00 & 1.00 \\
\hline Yes & 31.8 & $1.68(1.53-1.83)^{\dagger}$ & $1.69(1.54-1.86)^{\dagger}$ & 82.5 & $1.84(1.68-2.02)^{+}$ & $1.57(1.42-1.73)^{\dagger}$ \\
\hline \multicolumn{7}{|c|}{ Know the state's initial vaccination strategy } \\
\hline No & 24.9 & 1.00 & 1.00 & 68.3 & 1.00 & 1.00 \\
\hline Yes & 28.9 & $1.22(1.12-1.34)^{+}$ & $1.12(1.01-1.24)^{*}$ & 82.7 & $2.21(2.02-2.43)^{+}$ & $1.61(1.43-1.81)^{\dagger}$ \\
\hline \multicolumn{7}{|c|}{ Know the free vaccination policy } \\
\hline No & 26.5 & 1.00 & NU & 69.4 & 1.00 & 1.00 \\
\hline Yes & 28.1 & 1.08(0.98-1.19) & & 81.6 & $1.96(1.78-2.16)^{\dagger}$ & $1.40(1.24-1.58)^{\dagger}$ \\
\hline \multicolumn{7}{|c|}{ Worry about infection of $\mathrm{A} / \mathrm{H} 1 \mathrm{~N} 1$} \\
\hline No & - & - & - & 74.4 & 1.00 & 1.00 \\
\hline Yes & & & & 87.9 & $2.51(2.22-2.84)^{+}$ & $2.09(1.84-2.37)^{\dagger}$ \\
\hline \multicolumn{7}{|c|}{ Has your daily life been disturbed by A/H1N1 } \\
\hline No & - & - & - & 73.4 & 1.00 & NS \\
\hline Yes & & & & 87.2 & $2.47(2.22-2.76)^{+}$ & \\
\hline
\end{tabular}

$\mathrm{OR}_{\mathrm{u}}$ : univariate odds ratio obtained using logistic regression;

$\mathrm{OR}_{\mathrm{m}}$ : odds ratio obtained from stepwise multivariate logistics regression analysis using univariately significant variables as candidate variables and adjusting for gender, age, education level, occupation, region and survey wave;

NU: not significant in the univariate analysis;

NS: not significant in multivariate analysis though significant in the univariate analysis;

$-:$ not analyzed

*: $P<0.05$;

†: $P<0.0001$.

the risk of getting infected would increase when an infected person coughed or sneezed in close distance. This may be due to the previous experience of SARS and avian flu. Multivariate analysis results showed that workers and farmers with lower education level were less likely to have this knowledge, which indicated that the contents and forms of propaganda should be more understandable and acceptable. A large proportion of residents in our survey overlooked the indirect hand contact and hand-shaking transmission route and about one third of public misconceived that A/H1N1 was food borne, which was associated with the previous knowledge of avian flu and the new $\mathrm{A} / \mathrm{H} 1 \mathrm{~N} 1$ flu in the general population. The confusion with avian flu might mislead some residents to believe that the $\mathrm{A} / \mathrm{H} 1 \mathrm{~N} 1$ virus is fatal and cause public panic [19]. Therefore, it is important for the government and health authorities to provide continuously updated information of the emerging disease through televisions, newspapers, radios, and Internet.

There are regional differences in the perception of A/H1N1. For example, the public in Hong Kong did not perceive a high likelihood of having a local A/H1N1 outbreak [19], but Malaysians were particularly anxious about the pandemic [20]. The current study shows that emotional distress was relatively mild in China as few residents worried about being infected (25.1\%). This phenomenon may also be related to the previous experience of the SARS epidemic, as well as the open epidemic information. A survey in Korean university showed that women perceived higher illness severity and personal susceptibility to A/ H1N1 infection, which had been reconfirmed in our study [21]. Logistic regression analysis results suggested that women with higher educational level had higher perception of risk. As time went by, the knowledge about the main transmission route increased, but the risk perception of being infected in residents decreased, suggesting the positive effect of government policy regarding A/H1N1 infection prevention, as well as the promotion of the media.

The previous study presented various results of influencing factors on the the compliance with the preventive practices. The study in Saudi showed that older men with better education were more likely to take preventive practices [9]; female students in Korean washed hands more frequently during the peak pandemic period of $\mathrm{A} /$ H1N1 [21]; in another pandemic study in USA, younger people was found to have greater uptake of recommended behaviors but not for gender [16]. We found female with higher education took more precautionary behaviors, but office staffs and farmers took less comparing with students. While such differences could result from study population demographics, profound differences may also exist in the knowledge of $\mathrm{A} / \mathrm{H} 1 \mathrm{~N} 1$ and the perceptions of recommended behaviors in those countries. Adjusting for the background factors, the 
Table 5 Factors associated with $\mathrm{A} / \mathrm{H} 1 \mathrm{~N} 1$ vaccination uptake

\begin{tabular}{|c|c|c|c|}
\hline Variables & Vaccinated rate(\%) & $\mathrm{OR}_{\mathrm{u}}(95 \% \mathrm{Cl})$ & $\mathrm{OR}_{\mathrm{m}}(95 \% \mathrm{Cl})$ \\
\hline \multicolumn{4}{|c|}{ Know the main modes of transmission } \\
\hline No & 8.4 & 1.00 & NS \\
\hline Yes & 12.5 & $1.56(1.37-1.78)^{\ddagger}$ & \\
\hline \multicolumn{4}{|c|}{ Know the free vaccination policy } \\
\hline No & 2.3 & 1.00 & 1.00 \\
\hline Yes & 14.2 & $8.71(7.44-10.20)^{\ddagger}$ & $7.20(5.91-8.78)^{\ddagger}$ \\
\hline \multicolumn{4}{|c|}{ Know the state's initial vaccination strategy } \\
\hline No & 4.7 & 1.00 & 1.00 \\
\hline Yes & 13.6 & $3.18(2.67-3.77)^{\ddagger}$ & $1.33(1.08-1.64)^{\dagger}$ \\
\hline \multicolumn{4}{|c|}{ Has your daily life been disturbed by $\mathrm{A} / \mathrm{H} 1 \mathrm{~N} 1$} \\
\hline No & 9.1 & 1.00 & 1.00 \\
\hline Yes & 14.0 & $1.63(1.44-1.84)^{\ddagger}$ & $1.29(1.11-1.50)^{\ddagger}$ \\
\hline \multicolumn{4}{|c|}{ Would worry about infection of A/H1N1 } \\
\hline No & 10.5 & 1.00 & $\mathrm{NU}$ \\
\hline Yes & 11.6 & $1.12(0.98-1.28)$ & \\
\hline \multicolumn{4}{|c|}{ Is the state's initial vaccination strategy reasonable } \\
\hline No & 7.6 & 1.00 & NS \\
\hline Yes & 10.9 & $1.49(1.03-2.15) *$ & \\
\hline \multicolumn{4}{|c|}{ The reaction to the adverse reaction of $\mathrm{A} / \mathrm{H} 1 \mathrm{~N} 1$ vaccine } \\
\hline Not afraid & 14.8 & 1.00 & 1.00 \\
\hline Don't care & 1.4 & $0.08(0.06-0.11)$ & $0.08(0.05-0.11)^{\neq}$ \\
\hline Be afraid & 1.8 & $0.11(0.07-0.17)^{\dagger}$ & $0.07(0.04-0.11)^{\ddagger}$ \\
\hline \multicolumn{4}{|c|}{ Have taken up preventive measures in daily life } \\
\hline No & 7.5 & 1.00 & NS \\
\hline Yes & 11.7 & $1.64(1.38-1.93)^{\ddagger}$ & \\
\hline \multicolumn{4}{|c|}{ Have taken up seasonal influenza vaccine } \\
\hline No & 8.1 & 1.00 & 1.00 \\
\hline Yes & 43.5 & $7.09(5.55-9.07)^{\ddagger}$ & $4.69(3.53-6.23)^{\neq}$ \\
\hline
\end{tabular}

$\mathrm{OR}_{\mathrm{u}}$ : univariate odds ratio obtained using logistic regression;

$\mathrm{OR}_{\mathrm{m}}$ : odds ratio obtained from stepwise multivariate logistics regression analysis using univariately significant variables as candidate variables and adjusting for gender, age, education level, occupation, region and survey wave;

NU: not significant in the univariate analysis;

NS: not significant in multivariate analysis though significant in the univariate analysis;

*: $P<0.05$;

†: $P<0.01$;

$\neq: P<0.0001$.

multivariate logistic regression showed the possible relationship between knowledge and risk perception, knowledge and practices (odd ratios were 1.57 and 2.09, respectively), which indicated that good knowledge is important to enable individuals to have better attitudes and practices in influenza risk reduction. Similar findings were observed in other studies performed during A/ H1N1 pandemic in Singapore [22] and during SARS pandemic in Hong Kong [13]. Therefore, it is important to focus on inculcating the correct knowledge to individuals as it will influence both attitudes and practices.

Injecting vaccination is an effective measure to prevent infectious disease [23]. In China, the seasonal influenza vaccination is not included in the national immunization program and must be purchased by recipients. Those who are above 60 years old, the pupil and children in kindergarten, and people with chronic diseases are recommended to get inoculation. Data provided by China CDC in 2009 showed that the immunization rate of the seasonal flu in Chinese population was below 2\% [24], which was much lower than $7.5 \%$ in our study $(P<$ 0.0001). This phenomenon is partly due to the state's prior vaccination strategy for population at high risk such as students, teachers, healthcare workers and people with chronic disease, as well as the confusion between seasonal flu vaccine and $\mathrm{A} / \mathrm{H} 1 \mathrm{~N} 1$ vaccine in residents. People who couldn't access the $\mathrm{A} / \mathrm{H} 1 \mathrm{~N} 1$ vaccine may take up seasonal flu vaccine as preventive behaviors. The A/ $\mathrm{H} 1 \mathrm{~N} 1$ vaccine was not available in China until the middle of September 2009. All populations at high risk above three years old were invited for vaccination free of charge [25]. A survey among 868 European travelers showed 
$14.2 \%$ participants were vaccinated against pandemic influenza A/H1N1 [26], higher than $10.8 \%$ in our study $(P<$ 0.01 ). Our study also showed students and health care workers were more likely to take up, which may be due to the prior vaccination strategy. Multivariate stepwise logistic regression analysis, which allowed us to adjust for background factors, further showed the perceived risk of infection and the knowledge about the main modes of transmission related to $\mathrm{A} / \mathrm{H} 1 \mathrm{~N} 1$ vaccination were insignificantly, similar results seen in Lau's study[8]. Therefore, the vaccination rate of $\mathrm{A} / \mathrm{H} 1 \mathrm{~N} 1$ is not expected to increase even if the virus becomes more prevalent or the knowledge of its transmission mode improved. Additionally, the behavior of taking up $\mathrm{A} / \mathrm{H} 1 \mathrm{~N} 1$ vaccine was associated with perceptions of vaccine's safety and influence on daily life by $\mathrm{A} / \mathrm{H} 1 \mathrm{~N} 1$ as well as the knowledge about the free vaccination policy and the state's initial vaccination strategy. This suggests that improving the safety of vaccine, the acceptability of side effect and the knowledge about the state's strategy related to $\mathrm{A} / \mathrm{H} 1 \mathrm{~N} 1$ vaccination in residents may be helpful to promote $\mathrm{A} / \mathrm{H} 1 \mathrm{~N} 1$ vaccination in the general population.

The cross-sectional telephone survey adopted in the study has some limitations. We were unable to interview the people who did not have phones and the depth of the questionnaire was largely limited because questions and pre-existing answers could not be too long and complex. In addition, the telephone response rate was $46.8 \%$, which means more than half of the interviewees rejected or didn't finish the survey. It was impossible to compare the difference between respondents and nonrespondents due to the lack of their basic information.

\section{Conclusions}

This $\mathrm{A} / \mathrm{H} 1 \mathrm{~N} 1$ epidemic has not caused public panic yet, but the knowledge of $\mathrm{A} / \mathrm{H} 1 \mathrm{~N} 1$ in residents is not optimistic as most of them confused the transmission route of $\mathrm{A} / \mathrm{H} 1 \mathrm{~N} 1$. There are many factors influencing the KAP related to A/H1N1. Female with higher educational level had higher perceived risk of infection and took more precautionary behaviors. Public education campaign may take the side effects of vaccine and the knowledge about the state's vaccination strategy into account. The data collected in this survey could be used as baseline data to monitor public perceives and behaviors in the event of future outbreak of infectious disease in China.

\section{Additional material}

Additional file 1: Questionnaire. The Questionnaire to Survey the Leve of Knowledge, Attitude and Practice in Different Stages of H1N1

Pandemic by Telephone in China.

\section{Acknowledgements}

No external funding was received in support of this study. We thank the respondents in this study for their cooperation and the investigators from three universities in China (the Master students from Tongji Medical College, Ph.D Canqing Yu from Beijing University and Ph.D Hao Xiang from Wuhan University) and Doctor Wei Liu from Xi'an CDC; Rong Zhou for advice on data analysis; Li Liu and Qi Wang and Wenhua Kong for comments on the manuscript.

\section{Author details}

${ }^{1}$ Department of Epidemiology and Biostatistics, School of Public Health, Tongji Medical College, Huazhong University of Science and Technology, Wuhan 430030, China. 'Office for Disease Control and Emergency Response, Chinese Centre for Disease Control and Prevention (CDC), Beijing 10013, China.

\section{Authors' contributions}

HY and YX participated in design and coordination, and helped to draft the manuscript. $Y L$ and $\mathrm{LH}$ participated in the telephone investigations and analyzed the data and drafted the manuscript. SN conceived of the study, participated in its design and coordination. ZL participated in collection and management of data. WY participated in design and coordination, and helped to revise the manuscript. All authors read and approved the final manuscript.

\section{Competing interests}

The authors declare that they have no competing interests.

Received: 22 September 2010 Accepted: 16 May 2011

Published: 16 May 2011

\section{References}

1. Girard MP, Tam JS, Assossou OM, Kieny MP: The 2009 A (H1N1) influenza virus pandemic: A review. Vaccine 2010, 28:4895-4902.

2. Miller $E$, Hoschler $K$, Hardelid P, Stanford E, Andrews N, Zambon M: Incidence of 2009 pandemic influenza A H1N1 infection in England: a cross-sectional serological study. Lancet 2010, 375:1100-1108.

3. Pandemic (H1N1) 2009-update105. Geneva: World Health Organization; [http://www.who.int/csr/don/2010_06_18/en/index.html], Accessed Jun 29, 2010.

4. Cowling BJ, Chan KH, Fang VJ, Lau LL, So HC, Fung RO, Ma ES, Kwong AS, Chan CW, Tsui WW, Ngai HY, Chu DW, Lee PW, Chiu MC, Leung GM, Peiris JS: Comparative epidemiology of pandemic and seasonal influenza A in households. N Engl J Med 2010, 362:2175-2184.

5. Fraser C, Donnelly CA, Cauchemez S, Hanage WP, Van Kerkhove MD, Hollingsworth TD, Griffin J, Baggaley RF, Jenkins HE, Lyons EJ, Jombart T, Hinsley WR, Grassly NC, Balloux F, Ghani AC, Ferguson NM, Rambaut A, Pybus OG, Lopez-Gatell H, Alpuche-Aranda CM, Chapela IB, Zavala EP, Guevara DM, Checchi F, Garcia E, Hugonnet S, Roth C, WHO Rapid Pandemic Assessment Collaboration: Pandemic potential of a strain of influenza A (H1N1): early findings. Science 2009, 324:1557-1561.

6. Shen Y, Lu H: Pandemic (H1N1) 2009, Shanghai, China. Emerg Infect Dis 2010, 16:1011-1013.

7. The progress of National Prevention and Control of Influenza H1N1 in November 2009. Beijing, Ministry of Health of People's Republic of China. [http://www.moh.gov.cn/publicfiles/business/htmlfiles/mohwsyjbgs/ s7863/200912/44826], Accessed Nov 18, 2010.

8. Lau JT, Yeunga NC, Choi KC, Cheng MY, Tsui HY, Griffiths S: Factors in association with acceptability of $\mathrm{A} / \mathrm{H} 1 \mathrm{~N} 1$ vaccination during the influenza $\mathrm{A} / \mathrm{H} 1 \mathrm{~N} 1$ pandemic phase in the Hong Kong general population. Vaccine 2010, 28:4632-4637.

9. Blendon RJ, Benson JM, DesRoches CM, Raleigh E, Taylor-Clark K: The public's response to severe acute respiratory syndrome in Toronto and the United States. Clin Infect Dis 2004, 38(7):925-931.

10. Lau JT, Yang $X$, Tsui $H$, Kim JH: Monitoring community responses to the SARS epidemic in Hong Kong: from day 10 to day 62. J Epidemiol Community Health 2003, 57:864-870.

11. Zhong NS, Wong GW: Epidemiology of severe acute respiratory syndrome (SARS): adults and children. Paediatr Respir Rev 2004, 5:270-274. 
12. Sadique MZ, Edmunds WJ, Smith RD, Meerding WJ, Zwart O, Brug J, Beutels P: Precautionary behavior in response to perceived threat of pandemic influenza. Emerg Infect Dis 2007, 13:1307-1313.

13. Deng JF, Olowokure B, Kaydos-Daniels SC, Chang HJ, Barwick RS, Lee ML, Deng CY, Factor SH, Chiang CE, Maloney SA, The SARS International Field Team: Severe acute respiratory syndrome (SARS): knowledge, attitudes, practices and sources of information among physicians answering a SARS fever hotline service. Public Health 2006, 120:15-19.

14. de Zwart O, Veldhuijzen IK, Elam G, Aro AR, Abraham T, Bishop GD, Richardus JH, Brug J: Avian influenza risk perception, Europe and Asia. Emerg Infect Dis 2007, 13:290-293.

15. Di Giuseppe G, Abbate R, Albano L, Marinelli P, Angelillo IF: A survey of knowledge, attitudes and practices towards avian influenza in an adult population of Italy. BMC Infect Dis 2008, 8:36.

16. Rubin GJ, Amlot R, Page L, Wessely S: Public perceptions, anxiety, and behaviour change in relation to the swine flu outbreak: cross sectional telephone survey. BMJ 2009, 339:b2651.

17. Effler PV, Carcione D, Giele C, Dowse GK, Goggin L, Mak DB: Household responses to pandemic (H1N1) 2009-related school closures, Perth, Western Australia. Emerg Infect Dis 2010, 16:205-211.

18. Fitzgerald DA: Human swine influenza A [H1N1]: practical advice for clinicians early in the pandemic. Paediatr Respir Rev 2009, 10:154-158.

19. Lau JT, Griffiths S, Choi KC, Tsui HY: Widespread public misconception in the early phase of the H1N1 influenza epidemic. J Infect 2009, 59:122-127.

20. Goodwin R, Haque S, Neto F, Lynn B, Myers LB: Initial psychological responses to Influenza A, H1N1 ("Swine flu"). BMC Infectious Diseases 2009, 9:166.

21. Park JH, Cheong HK, Son DY, Kim SU, Ha CM: Perceptions and behaviors related to hand hygiene for the prevention of H1N1 influenza transmission among Korean university students during the peak pandemic period. BMC Infectious Diseases 2010, 10:222.

22. Yap J, Lee VJ, Yau TY, Ng TP, Tor PC: Knowledge, attitudes and practices towards pandemic influenza among cases, close contacts, and healthcare workers in tropical Singapore: a cross-sectional survey. BMC Public Health 2010, 10:442.

23. Hsieh YH: Age groups and spread of influenza: implications for vaccination strategy. BMC Infect Dis 2010, 10:106.

24. The latest data: the immunization rate of the seasonal flu was below $2 \%$ in China. [http://health.people.com.cn/GB/14740/22121/9214398.html], Accessed Nov 10, 2010..

25. The guide for influenza $A(H 1 N 1)$ vacation in China: Beijing, Ministry of Health of People's Republic of China. [http://61.49.18.65/publicfiles// business/htmlfiles/H1N1/s10628/list.htm], Accessed Nov 15, 2010.

26. Pfeil A, Mütsch M, Hatz C, Szucs TD: A cross-sectional survey to evaluate knowledge, attitudes and practices (KAP) regarding seasonal influenza vaccination among European travelers to resource-limited destinations. BMC Public Health 2010, 10:402

\section{Pre-publication history}

The pre-publication history for this paper can be accessed here: http://www.biomedcentral.com/1471-2334/11/128/prepub

doi:10.1186/1471-2334-11-128

Cite this article as: Lin et al:: Knowledge, Attitudes and Practices (KAP) related to the Pandemic (H1N1) 2009 among Chinese General Population: a Telephone Survey. BMC Infectious Diseases 2011 11:128.

\section{Submit your next manuscript to BioMed Central and take full advantage of:}

- Convenient online submission

- Thorough peer review

- No space constraints or color figure charges

- Immediate publication on acceptance

- Inclusion in PubMed, CAS, Scopus and Google Scholar

- Research which is freely available for redistribution

Submit your manuscript at www.biomedcentral.com/submit
Biomed Central 